\title{
Effect of ferulic acid on the performance of soy protein isolate-based edible coatings applied to fresh-cut apples
}

\author{
M.M. Alves, M.P. Gonçalves, C.M.R. Rocha*,1 \\ REQUIMTE, LAQV, Departamento de Engenharia Química, Faculdade de Engenharia, Universidade do Porto, Rua Dr. Roberto Frias, 4200-465 Porto, Portugal
}

\section{A R T I C L E I N F O}

\section{Article history:}

Received 22 December 2016

Received in revised form

7 March 2017

Accepted 8 March 2017

Available online 10 March 2017

\section{Keywords:}

Fresh-cut apples

Browning

Edible coatings

Ferulic acid

Soy protein isolate

\begin{abstract}
A B S T R A C T
The economic importance of fresh-cut fruit market is becoming progressively more significant, while the food industry shows increased interest in innovation of products bringing health benefits.

The objective of this work was to assess the potential of incorporating ferulic acid (antioxidant with reported bioactivity that can act as cross-linking agent) in soy protein-based edible coating formulations in order to increase the quality and shelf life of fresh-cut apples (cv. Golden). Glycerol was used as plasticizer and ferulic acid was incorporated in concentrations between 1.0 and $4.0 \mathrm{~g} \mathrm{~L}^{-1}$. The properties of fresh-cut apples were analysed during seven days of storage at $10{ }^{\circ} \mathrm{C}$. A common commercial antioxidant (sodium ascorbate at $10 \mathrm{~g} \mathrm{~L}^{-1}$ ) was tested for comparison. Uncoated apples and apples dipped into antioxidants solution were used as controls.

The results emphasized the need to incorporate this phenolic antioxidant in a biopolymer matrix, due to its hydrophobic characteristics and consequently a poor dispersion along the surface of the fruit. They also indicate that the efficiency of the coatings incorporating ferulic acid is highly dependent on $\mathrm{pH}$. The formulation with ferulic acid at $4.0 \mathrm{~g} \mathrm{~L}^{-1}$ and $\mathrm{pH} 7.0$ has demonstrated potential application in extending the shelf life of fresh-cut apples.
\end{abstract}

() 2017 Elsevier Ltd. All rights reserved.

\section{Introduction}

Associated with lifestyles of modern consumers, the economic importance of the fresh-cut fruit industry is becoming progressively more significant (Tapia et al., 2008). Consumers are aware of the importance of a healthy diet, and at the same time, they request easy-prepared foods from the industry (De’Nobili, Pérez, Navarro, Stortz, \& Rojas, 2013). However, the commercial success of freshcut fruit has been limited due to their short life. When fruit are cut and peeled, their tissue responds with a steep rise in respiration rate, causing accelerated consumption of sugars, lipids and organic acids, and increasing ethylene production, which induces ripening and causes senescence (Kays, 1991, pp. 75-142). The shelf life and quality of cut fruit is further reduced by a series of decay processes also triggered by physical damage, including enzymatic browning, loss of texture, water loss, increased susceptibility to microbial spoilage, and production of undesirable odors and flavors (Olivas \&

\footnotetext{
* Corresponding author.

E-mail address: cmrochainv@gmail.com (C.M.R. Rocha).

1 Present address: CEB - Centre of Biological Engineering, University of Minho Campus de Gualtar, 4710-057 Braga, Portugal.
}

Barbosa-Cánovas, 2005). The process analysis becomes even more complicate as each fruit has different quality attributes to be maintained during the storage period (Falguera, Quintero, Jiménez, Muñoz, \& Ibarza, 2011) and each of them react differently to different treatments (Bico, Raposo, Morais, \& Morais, 2010).

Strategies for shelf life extension of fresh-cut fruits include packaging and processing technologies. Among packaging technologies, modified atmospheres and the choice of suitable packaging materials have been widely adopted to slow down the produce metabolism (Del Nobile, Licciardello, Scrocco, Muratore, \& Zappa, 2007). Various innovations are available today for limiting the quality loss, such as the use of ozone (Restuccia et al., 2014), non-thermal technologies (Moreira, Álvarez, Martín-Belloso, \& Soliva-Fortuny, 2017) and edible coatings (Bonilla, Atarés, Vargas, \& Chiralt, 2012). The application of edible coatings on fresh fruit and vegetables can reduce quality changes and quantity losses, through modification and control of the internal atmosphere of the individual fruit or vegetable (Dhall, 2013). Edible coatings are also useful as carriers for a broad range of food additives, including antibrowning agents, antioxidants, antimicrobials, colourants, flavors, nutrients and spices (Cerqueira et al., 2011; Falguera et al., 2011; Rojas-Graü, Oms-Oliu, Soliva-Fortuny, \& Martín-Belloso, 2009; 
Wihodo \& Moraru, 2013).

Therefore, several researchers have been studying the potential of various coating materials on increasing the quality and shelf life of fresh-cut fruit. Edible coatings can be prepared from proteins, polysaccharides, lipids or the combination of these components. Among them, protein-based edible coatings could be the most attractive, since protein films present impressive gas barrier and mechanical properties compared with those from lipids and polysaccharides (Azeredo \& Waldron, 2016; Ou, Kwok, \& Kang, 2004). Perez-Gago, Serra, and del Rio (2006) used a whey protein concentrate-based edible coating incorporating beeswax and ascorbic acid or cysteine to coat fresh-cut apples, with positive effect in the browning index but unable to control the weight loss.

Specifically, soy protein isolate (SPI) films have received a wide attention because of their low oxygen permeability, even when compared to the traditional low-density polyethylene film (Brandenburg, Weller, \& Testin, 1993; Cuq, Gontard, \& Guilbert, 1998; Ma et al., 2008), providing opportunities for preserving foods from oxidative deterioration. SPI is also an abundant and lowcost vegetable protein source, with nutritional quality and good biodegradability and biocompatibility (Cao, Fu, \& He, 2007a; Sui, Jiang, \& Yu, 2012; Wang, Marcone, Barbut, \& Lim, 2012). Although several studies can be found in the literature concerning the properties and applications of SPI based edible films (Brandenburg et al., 1993; Choi, Kim, Hanna, Weller, \& Kerr, 2003; Gennadios, Brandenburg, Weller, \& Testin, 1993; Kang, Wang, Zhang, Li, \& Zhang, 2016; Kim, Marx, Weller, \& Hanna, 2003; Park, Rhee, Bae, \& Hettiarachchy, 2001; Wang et al., 2012; Wihodo \& Moraru, 2013; Zhang et al., 2010), few information can be found regarding the application of SPI edible coatings, namely in fresh-cut fruit. In a recent study (Marquez et al., 2017), reported reduced weight loss in fresh-cut apples coated with SPI or whey protein isolate. Ghidelli, Mateos, Rojas-Argudo, and Pérez-Gago (2015) also reported positive effects of a SPI-based coating formulation (incorporating beeswax) applied in combination with modified atmospheres to fresh-cut artichoke. In another study (Shon \& Choi, 2011), the effectiveness of edible coatings containing SPI was demonstrated in reducing moisture loss of apples and potatoes in a five days period, particularly in combination with CMC, though final moisture loss for the best formulation was still over $20 \%$. However, though the authors claim positive effects on oxidative discolouration, the colour study was terminated after $120 \mathrm{~min}$ due to excessive browning, which is clearly ineffective.

In spite of its low oxygen permeability, SPI films have been reported to be an ineffective moisture barrier (Gennadios et al., 1993; Ou, Wang, Tang, Huang, \& Jackson, 2005; Park et al., 2001; Zink, Wyrobnik, Prinz, \& Schmid, 2016), as expected for highly polar polymer films. Cross-linking using physical, chemical or enzymatic treatments has been explored by several researchers as a viable method to improve the mechanical strength and barrier properties of protein films (Azeredo \& Waldron, 2016; Wihodo \& Moraru, 2013). Chemical treatments include the use of cross-linking agents such as ferulic acid. Ferulic acid is one of the most abundant phenolic acids in plants, acting as a cross-linking agent in cell walls (Liyama, Lam, \& Stone, 1984). Some recent studies have demonstrated that ferulic acid could act as satisfactory crosslinking agent in preparation of SPI, gelatin, starch-chitosan and sodium caseinate based edible films (Cao, Fu, \& He, 2007b; Fabra, Hambleton, Talens, Debeaufort, \& Chiralt, 2011; Mathew \& Abraham, 2008; Ou et al., 2005). Other phenolic compounds have also been used as crosslinking agents in SPI films such as rutin, epicatechin, caffeic acid or gallic acid (Friesen, Chang, \& Nickerson, 2015; Insaward, Duangmal, \& Mahawanich, 2015). Ferulic acid can cross-link with proteins and polysaccharides by several mechanisms. In case of proteins, ferulic acid can oxidize to its quinone and then the quinone further react with amines on the protein, or it can cross-link with tyrosine and other amino acids through a free radical mechanism; a third possibility is its esterification with hydroxyl amino acids such as serine (Ou et al., 2005). Ou et al. (2005) demonstrated that an optimal concentration of ferulic acid incorporated in the SPI film increased the tensile strength, percent elongation at break and antioxidant activity of films for preservation of fresh lard.

Besides its low toxicity and cross-linking properties with both polysaccharides and proteins, ferulic acid has been also reported to have many physiological functions, including antioxidant, antimicrobial, anti-inflammatory, anti-thrombotic and anti-cancer activities (Ou \& Kwok, 2004). It also protects against coronary disease, lowers cholesterol and increases sperm viability (Ou \& Kwok, 2004). As emphasized in a recent paper (De'Nobili et al., 2013), the food industry shows an increased interest in product innovation which brings specific health benefit and the additives used in healthier food formulations should be as natural as possible.

The aim of this study was to assess the potential of the application of SPI based edible coatings, incorporating ferulic acid, in order to extend the shelf life of fresh-cut apples.

Though ferulic acid has been described as a good cross-linking agent for protein films, as described above, the incorporation of ferulic acid in SPI edible coatings applied to food was never studied, to our knowledge. Furthermore, the antioxidant and bioactive properties of ferulic acid can be an important feature for fresh-cut fruit applications. For this purpose, the weight loss and colour of cut apples, the two main quality indicator parameters chosen for this work, were evaluated during seven days, at $10{ }^{\circ} \mathrm{C}$ and $50 \%$ relative humidity (RH). For the selected formulations, apples were also analysed for firmness, $\mathrm{pH}$ and soluble solids content. Preliminarily, the water vapour permeability of films (WVP) with the same coating formulations was investigated. The effect of the application of SPI coatings, incorporating another antioxidant commonly used (namely, sodium ascorbate), on the quality of fresh-cut apples was also analysed, for comparison. Uncoated apples and apples dipped into solutions of the two antioxidants, under analysis, were used as controls.

\section{Materials and methods}

\subsection{Materials}

SPI (Ref. 20120201), with an isoelectric point of 4.6, and sodium ascorbate (Ref. 01010503) were kindly supplied by Formulab Aditivos Alimentares, Ltd. Ferulic acid (Ref. 128708) were purchased from Sigma Aldrich Ltd and glycerol (Ref. 1.04092.1000) was purchased from Merck Ltd (E-301).

Apples (Golden Delicious, Portugal) were obtained from a local supermarket, between February and Abril 2013. Transport took about $10 \mathrm{~min}$ and they were immediately stored at $4{ }^{\circ} \mathrm{C}$ until processing. The average $\mathrm{pH}$ of the pulp of the apples was 4.5 .

\subsection{Methods}

\subsubsection{Preparation of film/coating formulations}

The film/coating formulations were prepared with SPI at a concentration of $30 \mathrm{~g} \mathrm{~L}^{-1}$ and glycerol (Gly) was added, as plasticizer, to a final concentration of $9.0 \mathrm{~g} \mathrm{~L}^{-1}$ (corresponding to $30 \% \mathrm{w} /$ $\mathrm{w}$ of polymer - SPI).

Sodium ascorbate (SA) was incorporated at a concentration of $10 \mathrm{~g} \mathrm{~L}^{-1}$ and ferulic acid (FA) was incorporated at four concentrations: $1.0,2.0,3.0$ and $4.0 \mathrm{~g} \mathrm{~L}^{-1}$.

Firstly, SPI solutions were prepared by dispersing the power in distilled water at room temperature for $1 \mathrm{~h}$, followed by heating the 
dispersion at $85^{\circ} \mathrm{C}$ for $30 \mathrm{~min}$.

To prepare the film/coating solutions, the required amounts of SPI solution, Gly and antioxidants (SA or FA) were dispersed in distilled water. The mixtures were stirred for $1 \mathrm{~h}$, at room temperature. The formulations with ferulic acid incorporated were prepared without $\mathrm{pH}$ adjustment and adjusting the $\mathrm{pH}$ to 7.0, using a $0.1 \mathrm{~mol} \mathrm{~L}^{-1} \mathrm{NaOH}$ solution. A summary of the used formulations and respective code is presented in Table 1.

\subsubsection{Film preparation}

To produce films, a constant amount $(25 \mathrm{~mL})$ was cast onto an $8.5 \mathrm{~cm}$ diameter Petri plate coated with Teflon ${ }^{\circledR}$. The films were dried in a climatic chamber at $50{ }^{\circ} \mathrm{C}$ during $2 \mathrm{~h}$ and were maintained at $23{ }^{\circ} \mathrm{C}$ and $53 \% \mathrm{RH}$ (in a desiccator with a saturated solution of magnesium nitrate), at least $48 \mathrm{~h}$, before performing their characterisation.

\subsubsection{Film properties}

Film thickness was measured using a digital micrometer (Mitutoyo Co., Japan, model ID-F150), at five random locations on the film's surface, for three different films, from which an average was obtained.

The WVP of the films was determined gravimetrically according to ASTM method 96 (1996). Three determinations were made for each formulation.

\subsubsection{Apples preparation and coating application}

Apples of homogeneous colour (light green, starting to get yellow), size and without physical damages were selected and cleaned with distilled water. Apples were peeled and sliced on a plastic board with a sharp cutting knife. The average area of apples was cut into two pieces in the width direction and then twice at right angles along its length. Eight pieces from different apples, weighting in total approximately $80 \mathrm{~g}$, were used per package. At least three packages were prepared per treatment.

Selected coating formulations were applied by dipping the cut apples into each solution for $10 \mathrm{~s}$, at room temperature. After dipping, apples were air dried with the aid of a fan for $10 \mathrm{~min}$. Then, they were placed in closed polyethylene terephthalate packages (commercial packages in the form of boxes with incorporated lids in the same material and thickness) and immediately stored in a climatic chamber, at $10{ }^{\circ} \mathrm{C}$ and $50 \% \mathrm{RH}$, for $7 \mathrm{~d}$.

\subsubsection{Weight loss and colour of the apples}

The weight loss of the apples was measured gravimetrically and expressed as a percentage of the initial apple weight.

Colour was measured with a Minolta colourimeter CR 300 (Tokyo, Japan), using the CIELAB colour parameters, lightness, $\mathrm{L}^{*}(0$ [black] to 100 [white]), and chromaticity parameters a* (green [-60] to red $[+60]$ ) and $b^{*}$ (blue $[-60]$ to yellow $[+60]$ ). The colour was also expressed as browning index, according to Buera, Petriella, and

Table 1

Samples formulations and respective codes.

\begin{tabular}{lll}
\hline Film or coating formulation & $\mathrm{pH}$ & Sample code \\
\hline $30 \mathrm{~g} \mathrm{~L}^{-1} \mathrm{SPI}-9.0 \mathrm{~g} \mathrm{~L}^{-1} \mathrm{Gly}$ & 7.1 & SPIG \\
$30 \mathrm{~g} \mathrm{~L}^{-1} \mathrm{SPI}-9.0 \mathrm{~g} \mathrm{~L}^{-1} \mathrm{Gly}-10 \mathrm{~g} \mathrm{~L}^{-1} \mathrm{SA}$ & 7.1 & SPISA \\
$30 \mathrm{~g} \mathrm{~L}^{-1} \mathrm{SPI}-9.0 \mathrm{~g} \mathrm{~L}^{-1} \mathrm{Gly}-1.0 \mathrm{~g} \mathrm{~L}^{-1} \mathrm{FA}$ & 6.1 & SPIFA1 \\
$30 \mathrm{~g} \mathrm{~L}^{-1} \mathrm{SPI}-9.0 \mathrm{~g} \mathrm{~L}^{-1} \mathrm{Gly}-2.0 \mathrm{~g} \mathrm{~L}^{-1} \mathrm{FA}$ & 5.5 & SPIFA2 \\
$30 \mathrm{~g} \mathrm{~L}^{-1} \mathrm{SPI}-9.0 \mathrm{~g} \mathrm{~L}^{-1} \mathrm{Gly}-3.0 \mathrm{~g} \mathrm{~L}^{-1} \mathrm{FA}$ & 5.2 & SPIFA3 \\
$30 \mathrm{~g} \mathrm{~L}^{-1} \mathrm{SPI}-9.0 \mathrm{~g} \mathrm{~L}^{-1} \mathrm{Gly}-4.0 \mathrm{~g} \mathrm{~L}^{-1} \mathrm{FA}$ & 5.1 & SPIFA4 \\
$30 \mathrm{~g} \mathrm{~L}^{-1} \mathrm{SPI}-9.0 \mathrm{~g} \mathrm{~L}^{-1} \mathrm{Gly}-1.0 \mathrm{~g} \mathrm{~L}^{-1} \mathrm{FA}$ & 7.0 & SPIFA1 $\mathrm{pH} 7$ \\
$30 \mathrm{~g} \mathrm{~L}^{-1} \mathrm{SPI}-9.0 \mathrm{~g} \mathrm{~L}^{-1} \mathrm{Gly}-2.0 \mathrm{~g} \mathrm{~L}^{-1} \mathrm{FA}$ & 7.0 & SPIFA2 $\mathrm{pH} 7$ \\
$30 \mathrm{~g} \mathrm{~L}^{-1} \mathrm{SPI}-9.0 \mathrm{~g} \mathrm{~L}^{-1} \mathrm{Gly}-3.0 \mathrm{~g} \mathrm{~L}^{-1} \mathrm{FA}$ & 7.0 & SPIFA3 $\mathrm{pH} 7$ \\
$30 \mathrm{~g} \mathrm{~L}^{-1} \mathrm{SPI}-9.0 \mathrm{~g} \mathrm{~L}^{-1} \mathrm{Gly}-4.0 \mathrm{~g} \mathrm{~L}^{-1} \mathrm{FA}$ & 7.0 & SPIFA4pH7 \\
\hline
\end{tabular}

Lozano (1985):

Browning index $=100 \times(\mathrm{x}-0.31) / 0.172$, where $\mathrm{x}=\mathrm{X} /(\mathrm{X}+\mathrm{Y}+\mathrm{Z})[1]$

$\mathrm{X}, \mathrm{Y}$ and $\mathrm{Z}$ are the CIE tristimulus values.

This index has been successfully employed as an indicator of browning in fresh-cut coated fruit (Olivas \& Barbosa-Cánovas, 2005). The test was performed for each piece of apple and an average value was calculated.

To standardize differences in different apples' batches, the increase in browning index towards the initial value was also used. It was calculated as:

Increase in browning index $=((\mathrm{BIS}-\mathrm{BII}) / \mathrm{BII}){ }^{*} 100$

BIS is the browning index of the sample and BII is the initial browning index of the correspondent batch of apples.

\subsubsection{Firmness, $\mathrm{pH}$ and soluble solids content of apples}

The firmness of apples was evaluated through penetration tests, using a TA-XT2 (Stable Micro Systems) texture analyser, with a load cell of $5 \mathrm{~kg}$. The chosen procedure was similar to the one described by Cocci, Rocculi, Romani, and Dalla Rosa (2006) with small adjustments. A $6.0 \mathrm{~mm}$ diameter cylindrical probe was lowered at a cross-head speed of $0.50 \mathrm{~mm} / \mathrm{s}$ and penetrated $8.0 \mathrm{~mm}$ into the apples. Firmness (in N) was considered the maximum force obtained from the force $v s$ distance texturograms.

For $\mathrm{pH}$ and total soluble solids measurements, the content of each package was minced. $\mathrm{pH}$ was measured using a $\mathrm{pH}$ meter (Orion, model 320). The content of total soluble solids was determined with a hand refractometer (Atago, model PAL-RI) and the results were expressed in \% (AOAC, 2000).

\subsubsection{Statistical analyses}

Statistical analyses of the influence of different coating formulations on the apples quality after $7 \mathrm{~d}$ of storage were made using the data analysis software Statistica version 8.0 (StatSoft, Inc, Tulsa, USA). Analysis of variance (ANOVA) was performed after $7 \mathrm{~d}$ of storage. Variances were tested for homogeneity and statistical significant differences were analysed a posteriori with the Fisher's Least Significant Differences (LSD) test. The significance level was defined as $\mathrm{p} \leq 0.05$, for all tests.

\section{Results and discussion}

\subsection{Film properties}

The WVP of the SPI film and SPI films with incorporation of antioxidants is presented in Table 2. The thicknesses used in their calculations and the $\mathrm{pH}$ of the film-forming solutions are also presented.

The incorporation of all antioxidants without $\mathrm{pH}$ control generally led to an increase of the WVP of the SPI film, though this trend is not always consistent for ferulic acid. Films incorporating ferulic acid had lower WVP than films with ascorbate.

Ascorbate is a molecule with polar groups $(-\mathrm{OH})$ and with an appreciable molecular size. The hydroxyl groups of ascorbate increase the hydrophilicity of the protein matrix and the development of protein-ascorbate hydrogen bonds can reduce the intermolecular attractions between protein chains. Therefore, the presence of ascorbate molecules increases the water affinity of the film, aids the diffusion of water molecules and hence causes an increase in WVP.

The lower WVP obtained for films incorporating ferulic acid, compared with those obtained for films incorporating sodium 
Table 2

Values of $\mathrm{pH}$, thickness and WVP (mean \pm SD) for SPI edibles films with antioxidants incorporated.

\begin{tabular}{llll}
\hline Film & pH & $\begin{array}{l}\text { Thickness } \\
(\mathrm{mm})\end{array}$ & $\begin{array}{l}\text { WVP } \\
\left(\mathrm{ng} \mathrm{m}^{-1} \mathrm{~s}^{-1} \mathrm{~Pa}^{-1}\right)^{*}\end{array}$ \\
\hline SPIG & 7.1 & $0.136 \pm 0.014$ & $0.604 \pm 0.020^{\mathrm{a}, \mathrm{b}}$ \\
SPISA & 7.1 & $0.170 \pm 0.003$ & $0.801 \pm 0.055^{\mathrm{c}}$ \\
SPIFA1 & 6.1 & $0.157 \pm 0.012$ & $0.684 \pm 0.055^{\mathrm{d}, \mathrm{e}}$ \\
SPIFA2 & 5.5 & $0.143 \pm 0.006$ & $0.589 \pm 0.035^{\mathrm{a}, \mathrm{f}}$ \\
SPIFA3 & 5.2 & $0.160 \pm 0.008$ & $0.732 \pm 0.037^{\mathrm{d}}$ \\
SPIFA4 & 5.1 & $0.165 \pm 0.002$ & $0.590 \pm 0.023^{\mathrm{a}, \mathrm{f}}$ \\
SPIFA1 pH7 & 7.0 & $0.137 \pm 0.009$ & $0.692 \pm 0.035^{\mathrm{d}, \mathrm{e}}$ \\
SPIFA2 pH7 & 7.0 & $0.136 \pm 0.007$ & $0.661 \pm 0.039^{\mathrm{b}, \mathrm{e}}$ \\
SPIFA3 pH7 & 7.0 & $0.146 \pm 0.008$ & $0.670 \pm 0.026^{\mathrm{e}}$ \\
SPIFA4pH7 & 7.0 & $0.142 \pm 0.004$ & $0.534 \pm 0.030^{\mathrm{f}}$ \\
\hline
\end{tabular}

${ }^{*}$ Means with the same lower case letter, in the same column, did not differ significantly at $\mathrm{p} \leq 0.05$, according to the Fisher test.

ascorbate, can be explained by the low polarity of this phenolic antioxidant, which has both hydrophilic and hydrophobic character. Analysing the effect of the concentration of ferulic acid in the films without $\mathrm{pH}$ control, it is not possible to observe a regular trend in the WVP of the films. In part, the irregular trend may be attributed to the SPI aggregation, as a consequence of the decrease in the $\mathrm{pH}$ of films with increasing concentration of ferulic acid, approaching the isoelectric point of protein (around 4.6; as reported e.g. by Kim, Varankovich, \& Nickerson, 2016). It is well known that the structure and functional properties of proteins are highly influenced by pH. Gennadios et al. (1993) studied the effect of $\mathrm{pH}$ on properties of SPI films and demonstrated that the film formation was inhibited by poor protein dispersion around the isoelectric pH region. In another study, Brandenburg et al. (1993) demonstrated that when SPI was solubilized and crosslinks were developed at higher $\mathrm{pH}$ values than 6 , lower water vapour and oxygen permeability were achieved. Similarly, the work by PérezGago and Krochta (1999) indicated that the WVP of whey protein films were the highest at $\mathrm{pH} 4-5$.

Therefore, films incorporating ferulic acid were also prepared at $\mathrm{pH} 7.0$ and the WVP determined for comparison. Significant differences in WVP were observed for the highest concentration of ferulic acid (4.0 $\left.\mathrm{g} \mathrm{L}^{-1}\right)$ as compared to the values without $\mathrm{pH}$ control. At higher acid concentrations, the $\mathrm{pH}$ of the formulations decreased to values below 5.5. By increasing the $\mathrm{pH}$ to 7.0, away from the protein soy isoelectric point, a clear decrease in the WVP of the films is observed (Table 2). The most significant difference was observed for the concentration of $4.0 \mathrm{~g} \mathrm{~L}^{-1}$, for which the WVP obtained is even lower than that obtained for the film without incorporation of antioxidants. Ou and co-workers (Ou et al., 2005) verified that, for SPI films at pH between 8.0 and 9.0, the WVP did not significantly change when ferulic acid was added to the formulations in the concentration range between 0.5 and $1.0 \mathrm{~g} \mathrm{~L}^{-1}$, or even slightly increased at a higher concentration of $2.0 \mathrm{~g} \mathrm{~L}^{-1}$. Other authors (Cao et al., 2007b) also found that ferulic acid had small influence on WVP of gelatin films. The presumed reason was that ferulic acid had many hydroxyl groups, which could combine with water, so the apparent WVP did not change.

The results of the present work indicate that the incorporation of ferulic acid in the SPI films, above a certain concentration, improves the barrier effect to water vapour of the films, if the $\mathrm{pH}$ is adjusted away from the isoelectric point. It is probable that, at lower concentrations, the presence of hydroxyl groups of ferulic acid increases the water affinity of the film and hence the film permeability. At higher concentrations, the higher extent of crosslinking between ferulic acid and SPI contributes to a more compact structure, overlapping the effect of increased hydrophilicity provided by hydroxyl groups of ferulic acid molecules, and consequently contributing to lower WVP.

\subsection{Effect of the coating formulations on weight loss and colour of fresh-cut apples}

As emphasized in a review paper (Rojas-Argudo, del Rio, \& Pérez-gago, 2009), one of the main objectives of coating application is reducing fruit weight loss during storage. Colour changes in fresh-cut fruit have also been extensively reported and browning of fresh-cut apple wedges is a key quality attribute for consumer acceptance (Lee, Park, Lee, \& Choi, 2003; Rößle, Brunton, Gormley, Wouters, \& Butler, 2011). The weight loss and colour were the two main quality indicator parameters chosen in this work, to evaluate the potential of the coating formulations to increase the shelf life of the cut apples.

The effect of the concentration of ferulic acid in the coating formulation on the weight loss and colour of cut apples was analysed. The effect of the application of SPI formulations incorporating sodium ascorbate on the quality of fresh-cut apples was also evaluated for comparison. Uncoated apples and apples dipped into the two antioxidants solution were used as controls. Results are presented in Tables 3 and 4 for days 1, 3 and 7 (variations tend to be faster in the first day and get slower and slower with time, at least while no visual microorganisms growth is visible, which was always the case in these tests with coated apples); no extra information would be provided by days 2, 4 and 6 . Following films' results for WVP, it was considered that formulations SPIFA1pH7, SPIFA2pH7 and SPIFA3pH7 had a very similar behavior and only SPIFA3pH7 was tested. As for the formulations with ferulic acid without $\mathrm{pH}$ adjustment, the results were not conclusive and all formulations were maintained and tested as coatings.

The percentage of weight loss of apples coated with SPI formulations and respective controls, on the first, third and seventh days of storage are presented in Table 3.

For the two higher concentrations of ferulic acid (3.0 and $4.0 \mathrm{~g} \mathrm{~L}^{-1}$ ), and due to the results obtained in the films, the $\mathrm{pH}$ of the coating formulations was also adjusted to 7.0. In terms of formulations with ferulic acid, the best control of the weight loss, especially after the first day, was obtained for these latter formulations, in accordance with the WVP results. It is also noteworthy that the result was significantly better for the ferulic acid concentration of $4.0 \mathrm{~g} \mathrm{~L}^{-1}$, also in accordance with WVP results, demonstrating the high potential of this formulation for controlling water loss in fresh-cut apples.

Table 3

Percentage of weight loss (mean \pm SD) in the fresh-cut apples coated with SPI formulations and controls, during storage period at $10{ }^{\circ} \mathrm{C}$ and $50 \% \mathrm{RH}$.

\begin{tabular}{llll}
\hline & \multicolumn{3}{l}{ Weight loss $(\%)$} \\
\cline { 2 - 4 } & $1 \mathrm{~d}$ & $3 \mathrm{~d}$ & $7 \mathrm{~d}^{*}$ \\
\hline Controls & & & \\
\hline Uncoated & $4.0 \pm 1.8$ & $13.8 \pm 0.7$ & $26.5 \pm 3.7^{\mathrm{a}}$ \\
Dipped in solution $10 \mathrm{~g} \mathrm{~L}^{-1} \mathrm{SA}$ & $2.8 \pm 0.2$ & $5.7 \pm 0.1$ & $15.5 \pm 4.2^{\mathrm{b}}$ \\
$\quad$ Dipped in solution $4.0 \mathrm{~g} \mathrm{~L}^{-1} \mathrm{FA}$ & $3.7 \pm 1.8$ & $11.0 \pm 3.6$ & $16.7 \pm 2.3^{\mathrm{b}}$ \\
Coatings & & & \\
\hline SPIG & $5.4 \pm 0.7$ & $15.5 \pm 2.4$ & $28.2 \pm 3.4^{\mathrm{a}}$ \\
SPISA & $1.9 \pm 1.3$ & $5.4 \pm 2.9$ & $15.0 \pm 4.7^{\mathrm{b}}$ \\
SPIFA1 & $3.9 \pm 1.1$ & $14.3 \pm 0.6$ & $28.5 \pm 3.9^{\mathrm{a}}$ \\
SPIFA2 & $2.4 \pm 0.7$ & $10.1 \pm 0.6$ & $26.2 \pm 2.7^{\mathrm{a}}$ \\
SPIFA3 & $2.8 \pm 1.3$ & $7.4 \pm 1.8$ & $26.6 \pm 7.4^{\mathrm{a}}$ \\
SPIFA4 & $3.8 \pm 1.1$ & $16.1 \pm 0.1$ & $28.5 \pm 4.0^{\mathrm{a}}$ \\
SPIFA3 pH7 & $2.8 \pm 1.2$ & $5.8 \pm 3.1$ & $16.3 \pm 3.5^{\mathrm{b}}$ \\
SPIFA4pH7 & $1.1 \pm 0.7$ & $2.5 \pm 1.8$ & $9.5 \pm 3.6^{\mathrm{c}}$ \\
\hline
\end{tabular}

*Means with the same lower case letter, in the same column, did not differ significantly at $\mathrm{p} \leq 0.05$, according to the Fisher test. 
Table 4

Percentage of increase in browning index (mean $\pm \mathrm{SD}$ ) in the fresh-cut apples coated with SPI formulations and controls, during storage period at $10^{\circ} \mathrm{C}$ and $50 \% \mathrm{RH}$.

\begin{tabular}{llll}
\hline & \multicolumn{3}{l}{ Increase in browning index (\%) } \\
\cline { 2 - 4 } & $1 \mathrm{~d}$ & $3 \mathrm{~d}$ & $7 \mathrm{~d}^{*}$ \\
\hline Controls & & & \\
\hline Uncoated & $27.2 \pm 10.3$ & $35.4 \pm 9.2$ & $43.4 \pm 10.2^{\mathrm{a}}$ \\
Dipped in solution $10 \mathrm{~g} \mathrm{~L}^{-1} \mathrm{SA}$ & $7.48 \pm 3.54$ & $10.2 \pm 3.8$ & $12.4 \pm 2.1^{\mathrm{b}}$ \\
Dipped in solution $4.0 \mathrm{~g} \mathrm{~L}^{-1}$ FA & $10.4 \pm 8.9$ & $18.1 \pm 5.0$ & $29.3 \pm 6.6^{\mathrm{c}}$ \\
Coatings & & & \\
\hline SPIG & $27.4 \pm 3.7$ & $29.0 \pm 5.7$ & $37.8 \pm 4.1^{\mathrm{a}, \mathrm{c}}$ \\
SPISA & $0.6 \pm 3.6$ & $3.88 \pm 3.92$ & $8.26 \pm 2.77^{\mathrm{b}}$ \\
SPIFA1 & $29.9 \pm 0.6$ & $40.8 \pm 2.8$ & $62.9 \pm 2.2^{\mathrm{d}}$ \\
SPIFA2 & $20.2 \pm 7.7$ & $27.3 \pm 5.3$ & $61.3 \pm 1.1^{\mathrm{d}}$ \\
SPIFA3 & $7.9 \pm 1.5$ & $18.1 \pm 5.5$ & $51.0 \pm 7.3^{\mathrm{a}}$ \\
SPIFA4 & $7.1 \pm 3.4$ & $14.1 \pm 7.6$ & $59.9 \pm 5.3^{\mathrm{d}}$ \\
SPIFA3 pH7 & $2.1 \pm 2.8$ & $7.0 \pm 2.2$ & $21.3 \pm 2.9^{\mathrm{c}}$ \\
SPIFA4pH7 & $2.56 \pm 0.23$ & $8.82 \pm 3.03$ & $12.8 \pm 4.3^{\mathrm{b}}$ \\
\hline
\end{tabular}

*Means with the same lower case letter, in the same column, did not differ significantly at $\mathrm{p} \leq 0.05$, according to the Fisher test.

Concerning also the controls and commercial antioxidant (Table 3), it is possible to observe that the best result was still obtained for apples coated with the formulation incorporating ferulic acid $\left(4.0 \mathrm{~g} \mathrm{~L}^{-1}\right)$ at $\mathrm{pH}$ 7. This result enhances the potential of the former coating formulation, to increase the shelf-life of cut apples.

It is also interesting to note that, with the exception of the SPI formulation without the incorporation of antioxidants and formulations with ferulic acid without $\mathrm{pH}$ adjustment to 7.0, from the first day of storage, all treatments showed better results in controlling water loss in relation to the uncoated fruit. Within the controls, similar results were obtained for the apples dipped into both antioxidants solution. Within the coatings and contrary to what was observed by Shon and Choi (2011), the SPI coating was not effective in reducing the weight loss of apples from the first day. This result might be attributed to some aggregation of the SPI by contact with the surface of the apple which has a pH near the isoelectric point of the protein. Thus, contrary to what might be expected based on the results of WVP of the films, the formulation incorporating ascorbate was more effective in controlling weight loss in comparison to the formulation without incorporation of antioxidants. This result may be due to the additional protective effect provided by the interactions of the antioxidants with compounds at the surface of the apples, in accordance with the results obtained for the apples just dipped into the solutions of the respective antioxidants or controls.

Similar results were obtained for the evolution of the browning index of apples during the storage period (Table 4). Within the formulations with ferulic acid, the best result was again obtained for the SPIFA4pH7 formulation. This result can be attributed to the antioxidant and antimicrobial properties of ferulic acid. The effectiveness of this coating formulation in controlling the colour of the apples and the respective effect of $\mathrm{pH}$ is highlighted in Fig. 1. The results obtained for the uncoated apples and apples just dipped in the ferulic acid solution (controls) were represented for comparison. As can be seen, changing the $\mathrm{pH}$ of the coating formulation from 5.1 to 7.0, gives appreciable advantages, significantly reducing the rise of the browning index (Fig. 1a) and colour parameter $a^{*}$ (Fig. 1b), whose increase is associated with an increase in red colour, during the storage period of $7 \mathrm{~d}$, at $10^{\circ} \mathrm{C}$.

No relevant differences were observed for colour parameters $\mathrm{L}^{*}$ and $b^{*}$. It is also interesting to note that for the apples coated with the formulation without adjusting the $\mathrm{pH}$ to 7.0 , as well as for the control of ferulic acid, there was a marked increase of the browning index and of the parameter $\mathrm{a}^{*}$ between the third and the fourth day. This result suggests that ferulic acid is not acting as a cross-linking agent in the SPI edible film/coating if it is formed at a $\mathrm{pH}$ near the
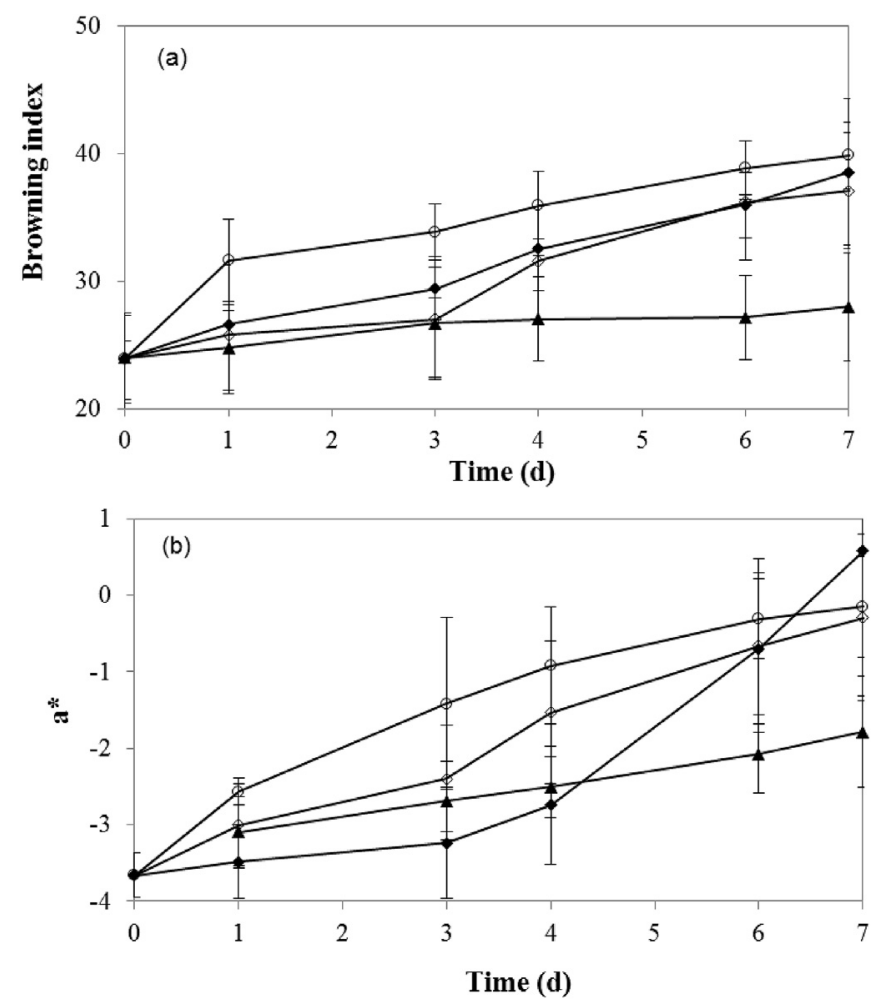

Fig. 1. The effect of $\mathrm{pH}$ of the coating formulations, with incorporation of ferulic acid (FA) at a concentration of $4.0 \mathrm{~g} \mathrm{~L}^{-1}$, on the evolution of browning index (a) and colour parameter $\mathrm{a}^{*}(\mathrm{~b})$ of fresh-cut apples (mean $\pm \mathrm{SD}$ ), during the storage period of $7 \mathrm{~d}$, at $10{ }^{\circ} \mathrm{C}$ and 50\% RH. Controls: $(\bigcirc)$ uncoated and $(\diamond) 4.0 \mathrm{~g} \mathrm{~L}^{-1}$ FA solution; Coatings: $(\diamond)$ SPIFA4 and ( $\boldsymbol{\Delta}$ ) SPIFA4pH7.

isoelectric point. Meanwhile, the results obtained at $\mathrm{pH} 7.0$ suggest a decrease in oxidative degradation of ferulic acid within the SPI network compared to the aqueous solution. The incorporation of antioxidant in the SPI matrix may help its stabilization because it can preclude its interaction with food compounds acting as an encapsulating agent. Moreover, it also provides its more uniform distribution along the surface of the fruit. In fact, for the apples just dipped into the solution of ferulic acid, it was possible to observe small insoluble aggregates of ferulic acid on their surface, which also highlight the need to incorporate this type of phenolic antioxidant, with both hydrophilic and hydrophobic behaviour, within a biopolymer matrix.

The fact that the apple coated with the formulation at $\mathrm{pH} 5.1$ showed a browning index higher than the apple just immersed in a solution of ferulic acid, and the very sharp increase of the parameter $a^{*}$ observed from the fourth day, can be attributed to the fact that the coating formed was not sufficiently cohesive and homogeneous due to aggregation of SPI near the isoelectric point. In this case, coating breakage due to non-homogeneous dispersion of SPI may occur, causing oxygen to come in contact with the apple surface, thus boosting browning.

Except for formulations with ferulic acid without $\mathrm{pH}$ adjustment, and regarding the control of browning index (Table 4), it is possible to observe that all treatments showed better results than the uncoated apples. Overall, the best results were obtained for the WPI formulation with antioxidants and with the traditional just dipping into ascorbate solution. In fact, all coating formulations incorporating antioxidant originated better results than those obtained with the coating formulation without incorporation of antioxidants. It is also to emphasize that the apples coated with formulations incorporating ferulic acid at $\mathrm{pH} 7$ present an evolution 
of browning index clearly lower than the obtained for the apples dipped into the solution of ferulic acid. This result can be attributed to the lower oxidative degradation of the antioxidants when they are incorporated into the SPI matrix compared to an aqueous solution, as already mention. Another possible reason for the reduction of the rise of browning index in apples, coated with formulation with incorporation of ferulic acid, is the effect of reducing the oxygen permeability. Ou et al. (2005) reported a decrease in the peroxide value of lard coated with films prepared with SPI and ferulic acid as a result of the lower oxygen permeability of this film.

\subsection{Effect of the selected formulations on firmness, $\mathrm{pH}$ and soluble solids content of fresh-cut apples}

Texture is also a critical factor for fruit quality and reflects metabolic changes and changes in water content (Rößle et al., 2011). Therefore, the formulation with ferulic acid that has proved most effective in controlling weight loss and browning index of fresh-cut apples (incorporation at $4.0 \mathrm{~g} \mathrm{~L}-1 \mathrm{FA}$ and $\mathrm{pH} 7.0$, SPIFA4pH7) was compared with formulations incorporating sodium ascorbate (SPISA) and respective controls. Due to the poor results achieved with the coating without antioxidants (SPIG), this formulation was also excluded in this last part of the study.

As can be observed in Fig. 2a, the most effective treatments for maintaining the firmness of apples, mainly reflected in the values obtained on the seventh day of storage, were dipping into the formulation incorporating ferulic acid and into the respective control.

The decrease in firmness observed on the third day of storage for apples that have not undergone any treatment can be attributed to degradation processes, whereas a significant increase on the seventh day is probably associated with significant weight loss observed for this sample in comparison with the treated samples (Table 3). Slightly higher firmness was achieved for apples coated with SPI and ferulic acid when comparing apples subjected to treatments with sodium ascorbate at the third day of storage. This result can be attributed to the fact that, as already mentioned, this antioxidant can act as cross-linker with polysaccharides present on the surface of apples, promoting a more rigid structure. The fact that the coated apples exhibit slightly higher values of firmness in relation to apples dipped into their respective controls can be attributed to the additional effect of edible protective barrier film on the surface of the fruit, and not to water loss, which was lower in the case of coating with ferulic acid, compared to its control (Table 3). On the seventh day, the treatment with ferulic acid is the most effective in controlling the firmness, with a final firmness very close to the one measured at day 3 . These more stable values are desirable in terms of the preservation of the food properties, during their storage period.

No significant differences were observed for the $\mathrm{pH}$ of cut apples, during the storage period under study and for the different treatments under analysis (results not presented).

Regarding the content of total soluble solids, and as can be observed in Fig. 2b, this parameter was not as sensitive to the treatment applied as was the firmness. However, on the seventh day of storage, a satisfactory result could also be observed for the treatments with ferulic acid. Since in this case, and as mention above, this result cannot be attributed, at all, to a high water content of the apples, the results suggest that the polysaccharide depolymerization involved in the increase of soluble solids content (Aguiar et al., 2011) may be most effectively controlled by the presence of ferulic acid.
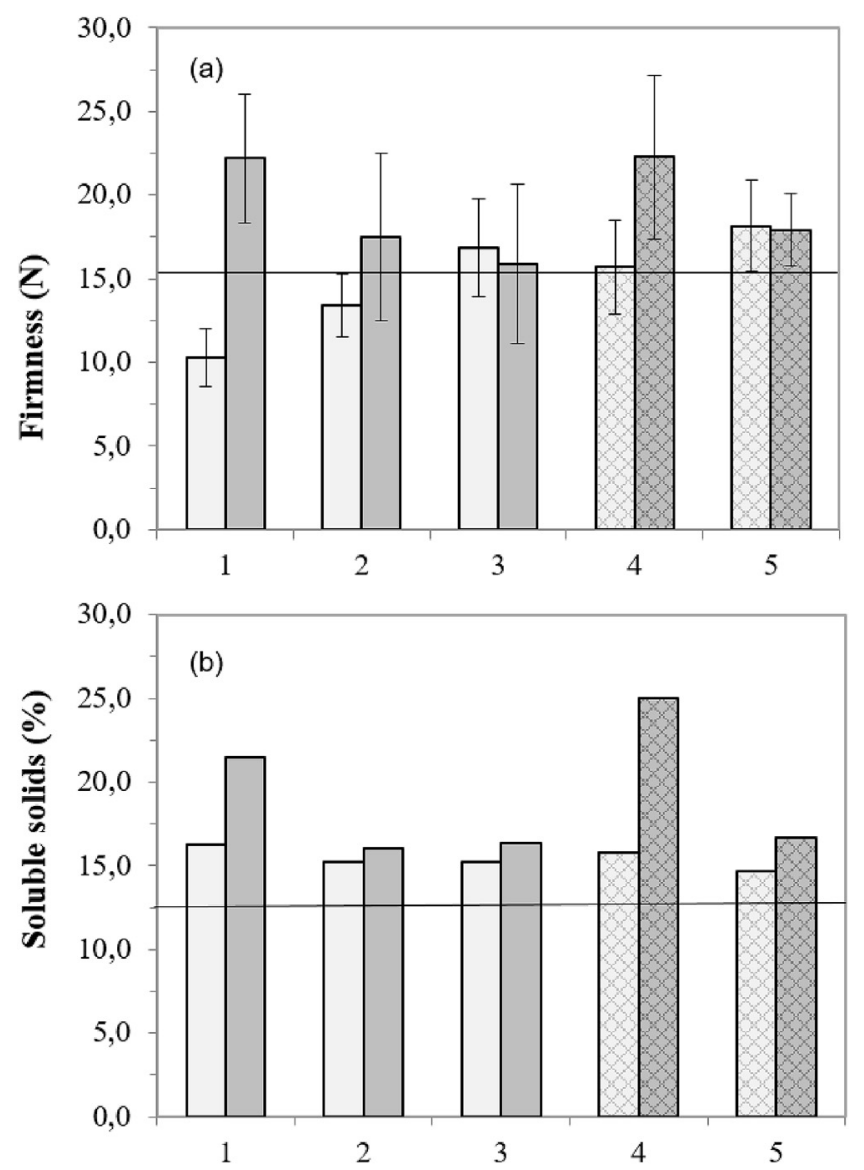

Fig. 2. Firmness (a) and soluble solids (b) of fresh-cut apples coated with SPI formulations and controls (mean $\pm \mathrm{SD}$ ), after 3 and $7 \mathrm{~d}$ of storage, at $10{ }^{\circ} \mathrm{C}$ and $50 \% \mathrm{RH} ;(-)$ initial value. Controls: (1) uncoated, (2) solution $10 \mathrm{~g} \mathrm{~L}^{-1} \mathrm{SA}$, (3) solution $4.0 \mathrm{~g} \mathrm{~L}^{-1} \mathrm{FA}$. Coatings: (4) SPISA and (5) SPIFA4pH7; 3 days, 7 days.

\section{Conclusions}

The results of this work demonstrate that the SPI based edible coatings, with incorporation of ferulic acid, present potential to extend the shelf life of fresh-cut apples.

The incorporation of ferulic acid at a concentration of $4.0 \mathrm{~g} \mathrm{~L}^{-1}$ in the SPI film-forming solution $\left(30 \mathrm{~g} \mathrm{~L}^{-1}\right)$, at $\mathrm{pH} 7.0$, sufficiently away from the isoelectric point of protein, decreases the WVP of the SPI film. This result can be attributed to the ferulic acid cross-linking properties with SPI and its hydrophobic character.

The application of this formulation to coat fresh-cut apples was effective in controlling their weight loss and firmness, when compared to uncoated apples or apples treated with more common antioxidants, namely sodium ascorbate. The results emphasized the need to incorporate this phenolic antioxidant in a biopolymer matrix, due to its hydrophobic characteristics and consequently a poor dispersion along the surface of the fruit. The SPI/ferulic acidbased coating formulation also evidenced a satisfactory result in terms of controlling the colour of cut apples and, in this case, the results obtained suggested a decrease in the oxidative degradation of ferulic acid, within SPI network compared to an aqueous solution.

It is also to highlight that ferulic acid, beyond being an abundant compound in the plant kingdom, with antioxidant and antimicrobial activities, presents several health benefits. 


\section{Acknowledgments}

Thanks are due to the European Community's Seventh Framework Programme (SusFoFlex, collaborative project number 289829, KBBE.2011.2.3-03). LAQV/REQUIMTE received financial support from FCT/MEC through national funds and FEDER, under the Partnership Agreement PT2020 (reference UID/QUI/50006/2013 - POCI/ 01/0145/FEDER/007265).

\section{References}

Aguiar, R. P., Miranda, M. R. A., Lima, A. M., Mosca, J. L., Moreira, R. A., \& Enéas Filho, J. (2011). Effect of a galactomannan coating on mango postharvest physicochemical quality parameters and physiology. Fruits, 66, 269-278.

AOAC. (2000). Official methods of analysis. Association of official analytical chemists (16 ${ }^{\text {th }}$ ed.). Arlington,VA: AOAC International.

ASTM D882-91, Philadelphia, PA. (1996). Annual book of ASTM. American Society for Testing and Materials.

Azeredo, H. M. C., \& Waldron, K. W. (2016). Crosslinking in polysaccharide and protein films and coatings for food contact - a review. Trends in Food Science \& Technology, 52, 109-122.

Bico, S. L. S., Raposo, M. F. J., Morais, R. M. S. C., \& Morais, A. M. M. B. (2010). Chemical dips and edible coatings to retard softening and browning of fresh-cut banana. International Journal of Postharvest Technology and Innovation, 2, 13-24.

Bonilla, J., Atarés, L., Vargas, M., \& Chiralt, A. (2012). Edible films and coatings to prevent the detrimental effect of oxygen on food quality: Possibilities and limitations. Journal of Food Engineering, 110, 208-213.

Brandenburg, A. H., Weller, C. L., \& Testin, R. F. (1993). Edible films and coatings from soy protein. Journal of Food Science, 58, 1086-1089.

Buera, M. P., Petriella, C., \& Lozano, R. D. (1985). Definition of colour in the nonenzymatic browning. Die Farbe, 33, 316-326.

Cao, N., Fu, Y., \& He, J. (2007a). Preparation and physical properties of soy protein isolate and gelatin composite films. Food Hydrocolloids, 21, 1153-1162.

Cao, N., Fu, Y., \& He, J. (2007b). Mechanical properties of gelatin films cross-linked, respectively, by ferulic acid and tannin acid. Food Hydrocolloids, 21, 575-584.

Cerqueira, M. A., Bourbon, A. I., Pinheiro, A. C., Martins, J. T., Souza, B. W. S. Teixeira, J. A., et al. (2011). Galactomannans use in the development of edible films/coatings for food applications. Trends in Food Science and Technology, 22, $662-671$.

Choi, S. G., Kim, K. M., Hanna, M. A., Weller, C. L., \& Kerr, W. L. (2003). Molecula dynamics of soy-protein isolate films plasticized by water and glycerol. Journal of Food Science, 68, 2516-2522.

Cocci, E., Rocculi, P., Romani, S., \& Dalla Rosa, M. (2006). Changes in nutritional properties of minimally processed apples during storage. Postharvest Biology and Technology, 39, 265-271.

Cuq, B., Gontard, N., \& Guilbert, S. (1998). Proteins as agricultural polymers for packaging production. Cereal Chemistry, 75, 1-9.

Del Nobile, M. A., Licciardello, F., Scrocco, C., Muratore, G., \& Zappa, M. (2007). Design of plastic packages for minimally processed fruits. Journal of Food Engineering, 79(1), 217-224.

De’Nobili, M. D. Pérez, C. D. Navarro, D. A. Stortz, C. A. \& Rojas, A. M. (2013). Hydrolytic stability of L-(+)-ascorbic acid in low methoxyl pectins films with potential antioxidant activity at food interfaces. Food and Bioprocess Technology, 6. 186-197.

Dhall, R. K. (2013). Advances in edible coatings for fresh fruits and vegetables: A review. Critical Reviews in Food Science and Nutrition, 53, 435-450.

Fabra, M. J., Hambleton, A., Talens, P., Debeaufort, F., \& Chiralt, A. (2011). Effect of ferulic acid and $\alpha$-tocopherol antioxidants on properties of sodium caseinate edible films. Food Hydrocolloids, 25, 1441-1447.

Falguera, V., Quintero, J. P., Jiménez, A., Muñoz, J. A., \& Ibarza, A. (2011). Edible films and coatings: Structures, active functions and trends in their use. Trends in Foo Science and Technology, 22, 292-303.

Friesen, K., Chang, C., \& Nickerson, M. (2015). Incorporation of phenolic compounds rutin and epicatechin, into soy protein isolate films: Mechanical, barrier and cross-linking properties. Food Chemistry, 172, 18-23.

Gennadios, A., Brandenburg, A. H., Weller, C. L., \& Testin, R. F. (1993). Effect of pH on properties of wheat gluten and SPI films. Journal of Agricultural and Food Chemistry, 41, 1835-1839.

Ghidelli, C., Mateos, M., Rojas-Argudo, C., \& Pérez-Gago, M. B. (2015). Novel approaches to control browning of fresh-cut artichoke: Effect of a soy proteinbased coating and modified atmosphere packaging. Postharvest Biology and Technology, 99, 105-113.

Insaward, A., Duangmal, K., \& Mahawanich, T. (2015). Mechanical, optical, and barrier properties of soy protein film as affected by phenolic acid addition. Journal of Agricultural and Food Chemistry, 63, 9421-9426.

Kang, H., Wang, Z., Zhang, W., Li, J., \& Zhang, S. (2016). Physico-chemical properties improvement of soy protein isolate films through caffeic acid incorporation and tri-functional aziridine hybridization. Food Hydrocolloids, 61, 923-932.
Kays, S. J. (1991). Metabolic processes in harvested products, in: Postharvest physiology of perishable plant products. New York: Van Nostrand Reinhold.

Kim, K. M., Marx, D. B., Weller, C. L., \& Hanna, M. A. (2003). Influence of sorghum, wax, glycerine and sorbitol on physical properties of soy protein isolates films. Journal of Food Science, 80, 71-76.

Kim, J. H. J., Varankovich, N. V., \& Nickerson, M. T. (2016). The effect of pH on the gelling behaviour of canola and soy protein isolates. Food Research International, $81,31-38$.

Lee, J. Y., Park, H. J., Lee, C. Y., \& Choi, W. Y. (2003). Extending shelf-life of minimally processed apples with edible coatings and antibrowning agents. LebensmittelWissenschaft-und-Technologie, 36, 323-329.

Liyama, K., Lam, T. B., \& Stone, B. (1984). Covalent cross-links in the cell wall. Plant Physiology, 104, 315-320.

Marquez, G. R., Di Pierro, P., Mariniello, L., Esposito, M., Giosafatto, C. V. L., \& Porta, R. (2017). Fresh-cut fruit and vegetable coatings by transglutaminase-crosslinked whey protein/pectin edible films. LWT-Food Science and Technology, 75, 124-130.

Mathew, S., \& Abraham, T. E. (2008). Characterisation of ferulic acid incorporated starch-chitosan blend films. Food Hydrocolloids, 22, 826-835.

Ma, D., Zhao, X., Ma, Y., Zhang, C., Yue, X., \& Li, C. (2008). Film forming property of different soy protein isolate produced by different technologies. Transactions of the Chinese Society of Agricultural Engineering, 24, 239-242.

Moreira, M. R. Álvarez, M. V., Martín-Belloso, O., \& Soliva-Fortuny, R. (2017). Effects of pulsed light treatments and pectin edible coatings on the quality of fresh-cut apples: A hurdle technology approach. Journal of the Science of Food and Agriculture, 97(1), 261-268.

Olivas, G. I., \& Barbosa-Cánovas, G. V. (2005). Edible coatings for fresh-cut fruits. Critical Reviews in Food Science and Nutrition, 45, 657-670.

Ou, S., \& Kwok, K. C. (2004). Ferulic acid: Pharmaceutical functions, preparation and application in foods. Journal of Science Food and Agriculture, 84, 1261-1269.

Ou, S. Y., Kwok, K. C., \& Kang, Y. J. (2004). Changes in in vitro digestibility and available lysine of soy protein isolate after formation of film. Journal of Food Engineering, 64, 301-305.

Ou, S., Wang, Y., Tang, S., Huang, C., \& Jackson, M. G. (2005). Role of ferulic acid in preparing edible films from soy protein isolate. Journal of Food Engineering, 70, 205-210.

Park, S. K., Rhee, C. O., Bae, D. H., \& Hettiarachchy, N. S. (2001). Mechanical properties and water-vapor permeability of soy-protein films affected by calcium salts and glucono-8-lactone. Journal of Agricultural and Food Chemistry, 49, $2308-2312$.

Pérez-Gago, M. B., \& Krochta, J. M. (1999). Water vapor permeability of whey protein emulsion films as affected by pH. Journal of Food Science, 64, 695-698.

Perez-Gago, M. B., Serra, M., \& del Rio, M. A. (2006). Color change of fresh-cut apples coated with whey protein concentrate-based edible coatings. Postharvest Biology and Technology, 39, 84-92.

Restuccia, C., Lombardo, S., Pandino, G., Licciardello, F., Muratore, G., \& Mauromicale, G. (2014). An innovative combined water ozonisation/O3atmosphere storage for preserving the overall quality of two globe artichoke cultivars. Innovative Food Science and Emerging Technologies, 21, 82-89.

Rojas-Argudo, C., del Rio, M. A., \& Pérez-gago, M. B. (2009). Development and optimization of locust bean gum (LBG)-based edible coatings for postharvest storage of "Fortune" mandarins. Postharvest Biology and Technology, 52, $227-234$

Rojas-Graü, M. A., Oms-Oliu, G., Soliva-Fortuny, R., \& Martín-Belloso, O. (2009). The use of packaging techniques to maintain freshness in fresh-cut fruits and vegetables: A review. International Journal of Food Science and Technology, 44, 875-889.

Rößle, C., Brunton, N., Gormley, R. T., Wouters, R., \& Butler, F. (2011). Alginate coating as carrier of oligofructose and inulin and to maintain the quality of fresh-cut apples. Journal of Food Science, 76, 19-29.

Shon, J., \& Choi, Y. H. (2011). Effect of edible coatings containing soy protein isolate (SPI) on the browning and moisture content of cut fruit and vegetables. Journal of Applied Biological Chemistry, 54, 190-196.

Sui, C., Jiang, L., \& Yu, G. (2012). Effects of pH on properties of soy protein isolate/ guar gum. Advanced Materials Research, 503, 446-449.

Tapia, M. S., Rojas-Graü, M. A., Carmona, A., Rodríguez, F. J., Soliva-Fortuny, R., \& Martin-Belloso, O. (2008). Use of alginate- and gellan-based coatings for improving barrier, texture and nutritional properties of fresh-cut papaya. Food Hydrocolloids, 22, 1493-1503.

Wang, S., Marcone, M., Barbut, S., \& Lim, L.-T. (2012). The impact of anthocyanin-rich red raspberry extract (ARRE) on the properties of edible soy protein isolate (SPI) films. Journal of Food Science, 77, 497-505.

Wihodo, M., \& Moraru, C. I. (2013). Physical and chemical methods used to enhance the structure and mechanical properties of protein films: A review. Journal of Food Engineering, 114, 292-302.

Zhang, C., Guo, K., Ma, Y., Ma, D., Li, X., \& Zhao, X. (2010). Incorporation of blueberry extracts into soybean-protein-isolate film preserve qualities of packaged lard. International Journal of Food Science and Technology, 45, 1801-1806.

Zink, J., Wyrobnik, T., Prinz, T., \& Schmid, M. (2016). Physical, chemical and biochemical modifications of protein-based films and Coatings: An extensive review. International Journal of Molecular Sciences, 17(9), 1376. 